\title{
Non-Invasive Papillary Squamous Cell
}

\section{Carcinoma}

National Cancer Institute

\section{Source}

National Cancer Institute. Non-Invasive Papillary Squamous Cell Carcinoma. NCI

Thesaurus. Code C65164.

A well differentiated squamous cell carcinoma characterized by a papillary, exophytic growth pattern, hyperkeratosis, and absence of invasion of adjacent tissues. 